DOI: https://doi.org/10.24867/02GI32Trifunovic

\title{
ОСНОВНЕ КАРАКТЕРИСТИКЕ И НАЧИН СПРОВОЪЕЊА ОСИГУРАҢА ОД ПОЖАРА У СРБИЈИ И СВЕТУ
}

\section{BASIC CHARACTERISTICS AND WAY OF TRANSACTION OF FIRE INSURANCE IN SERBIA AND THE WORLD}

\author{
Бранислав Трифуновић, Факултет техничких наука, Нови Сад
}

\section{ОбласТ - ИНЖЕЊЕРСКИ МЕНАЩМЕНТ}

Кратак садржај - Од својих почетака па до данас, осигурање од пожара се спроводи по начелу набројаних опасности. Полазећи од потреба развијених тржишта, пред крај деветнаестог века све више се почела ширити ова грана осигурања по начелу „сви ризици“. Поједностављено говорећи юоме, су покривени сви узрочии пожара осим оних који су изричито искључени из покрића. Тржитна пракса из многих делова света упућује на успешност сразмерно новог приступа закључења осигурања од пожара. Овај приступ се у Србији примењује мање од десет година. Налази из овог рада указују да се у будућности може очекивати још веће осавремењивање пожарног осигурања у намој земљи и да ће оно бити слично ономе у савременом свету.

Кључне речи: Осигурање од пожара, Начело набројаних опасности, Начело свих опасности, Осигурање у Србији

Abstract - From its beginnings to the present, fire insurance has been transacted according to the named perils principle. Proceeding from the needs of developed markets, at the end of the twentieth century this class of insurance has started to expand according to the all risks principle. To put it simply, all causes of fire are covered this way, except the ones that are explicitelly excluded. Market practices in a number of parts of the world refers to the effectiveness of the relatively new approach of taking out insurance. This approach has been practiced in Serbia for less than a decade. Findings from this graduation thesis show that in time to come we can expect modernisation of fire insruance to a greater extent in this country. Also, it will be similar to that in the modern world.

Keywords: Fire insurance, Named perils principle, All risks principle, Insurance in Serbia

\section{1. УВОД}

Осигурање од пожара јесте једна од најважнијих врста неживотних осигурања. Оно постоји више од три века и у њему се бележи велики обим премије. Без обзира на дуготрајну примену основних начела, оно

\section{НАПОМЕНА:}

Овај рад проистекао је из мастер рада чији ментор је био др Ђорђе Ћосић, ванр. проф. се и даље развија, посебно уколико га посматрамо са становишта примене приступа „сви ризици“. Готово на свим тржиштима пожарних осигурања израђују се и закључују полисе осигурања по овом начелу. Ипак, осигуравачи и реосигуравачи, нису никада у потпуности били спремни да пруже такво покриће, чак ни у развијеним земљама.

Основни предмет овог рада јесте анализа услова осигурања са становишта начела набројаних и свих ризика, са становишта предмета осигурања, као и поступка у случају остварења ризика. Такође, анализиран је и начин спровођења осигурања од пожара у Србији по највећим осигуравајућим друштвима. Полазна замисао у овом раду јесте да се укаже на неопходност даљег развоја осигурања од пожара код нас, посебно што се последњих година и у Србији нуди заштита по савременом принципу „сви ризици“.

\section{2. СПРОВОЪЕЊЕ ПОЖАРНОГ ОСИГУРАҢА У СРБИЈИ И СВЕТУ}

Полазећи од вишевековног искуства у свету и нашој земљи, можемо закључити да се осигурање од пожара спроводи на два начина.

Први, вишевековни, јесте „Осигурање од пожара по начелу набројаних опасности”, други, знатно новији, јесте „Осигурање од пожара по начелу свих опасности".

На основу доступних извора, закључујемо да се осигуравајућа пракса у нашој земљи традиционално заснивала на пружању пожарног покрића од именованих ризика, а не на основи „сви ризици“. Дакле, пожарно покриће именованих ризика представља традиционални приступ осигурања, док осигурање од „свих ризика“ представља савремени приступ у пожарном осигурању.

\section{1. Осигурање од пожара и неких других} опасности по начелу „именованих ризика“

Осигурање од пожара и неких других опасности по начелу именованих ризика пружа покриће покретних ствари која поседују физичка и правна лица. Предмет осигурања могу да буду све ствари, осим оних који су условима изричито искључени. Имовина која се осигурава по условима покрића пожарних ризика је:

- роба и залихе у трговинским и угоститељским организацијама и складиштима; 
- музеји, изложбене ствари, позоришта, биокопи, циркуси, сајмови и друге приредбе;

- залихе дрва и угља на слободном простору;

- шуме, срушена стабла и дрво на шумском простору;

- нискоградња.

Имовина која не може бити предмет покрића по условима ове врсте осигурања је:

- земљиште, непоплочана дворишта, насуте бране, насипи, обале и сл.;

- путеви без доњег строја;

- рибе и друге животиње у текућим и стајаћим водама;

- усеви у класу, плодови на таблу, родни и неродни засади изузев стабала воћакау оквиру окућнице;

- пловни објекти на води, ваздухоплови и роба у превозу.

Код пожарног осигурања индустрије и пожарног осигурања цивила, осигурањем се пружа осигуравајућа заштита од основних именованих ризика (пожар, удар грома, експлозија и др.). Ако се посебно утовори додатна премија осигурања, заштита се додатно проширује за један, или више допунских ризика. Осигуравач је у обавези да исплати штету само у случају непосредне штете, али не и посредну штету као што је штета услед губитка закупнине, губитака проузрокованих обуставом рада, умањења могућности употребе и других сличних губитака.

Ризик од пожара је један од највећих и најчешћих присутних опасности, па је с обзиром на то, веома значајно утврдити вредност ствари. Вредност осигуране ствари се утврђује на следећи начин [1]:

- за грађевинске објекте, грађевинска цена објекта према ценама у месту где се објекти налазе, умањена за износ процењеног рабаћења;

- за залихе робе, материјала и сировина, набавна цена, а ако је тржишна цена нижа од набавне тада је то тржишна цена увећана за зависне трошкове;

- за залихе полуготових и готових производа, производна цена;

- за машине, уређаје и инсталације, транспортна средства и средства везе, инвентар и предмете домаћинства, набавна цена нових ствари умањена за износ процењеног рабаћења.

Постоји основно правило утврђивања накнаде из осигурања:

- у случају уништења или нестанка ствари висина накнаде се утврђује према вредности осигуране ствари у време настанка осигураног случаја, умањеној за вредност остатка;

- у случају оштећења у висини трошкова оправке по ценама материјала и рада у време настанка осигураног случаја, умањено за износ процењеног рабаћења и вредности остатка.

\section{2. Осигурање од пожара по начелу свих опасности}

У иностраној пракси осигурања, полиса „сви ризици“ прилично је дуго присутна. Њени корени воде од полиса поморског осигурања и института „ризици мора“, тј. од временских непогода и пожарних ризика који су угрожавали бродове и терете који су превозили. Први такав облик се јавио у Енглеској почетком XVII века, када су стандардни услови осигурања, поред наведених поморских ризика садржавали и допуну покрића у виду формулације „и сви остали ризици“.

Прве идеје о осигурању од „свих ризика“ у имовинском осигурању уочавају се након завршетка Другог светског рата, посебно у конципирању специјалних покрића ради задовољења растуће тражње за осигурањем специфичних ствари као што су музејски излошци, музички инструменти или накит од „свих врста оштећења“ [2].

Једно од значајних обележја савременог тржишта осигурања је растућа тражња уговарача осигурања за покривањем ризика од елементарних непогода и политичких ризика, који су у стандардним условима пожарног осигурања искључени. Растућој тражњи за полисама „сви ризици“ доприноси низ фактора попут:

- непрекидан раст броја становника у свету;

- велика усредсређеност вредности у индустријским центрима;

- појава нових технологија;

- тежња утоварача осигурања да што пре закључи полису осигурања у региону са високим и недовољно познатим степеном угрожености.

Почетком XXI века, концепт полиса „сви ризици“ у редовном имовинском осигурању је почео да се шири Европом, када су га посредници преузели из праксе осигуравача САД-а и Велике Британије. На почетку XXI века осигуравајућа делатност се суочила са новим ризицима који су се развили из достигнутог нивоа развоја националних привреда. Концепт либерализације светског тржишта допринео је нестанку надгледаног и регулисаног система који је постојао деценијама.

Осигурање од „свих ризика“ је појам којим се одређује осигуравајуће покриће које није ограничено на штете настале дејством било којег одређеног ризика. Светска искуства указују да пожарне полисе „сви ризици“ излазе у сусрет потребама осигураника тиме што им пружају широку, кориснички блиску дефиницију ризика на основу којих настаје обавеза осигуравача.

Обавеза осигуравача постоји у свим случајевима у којима узрок штете није изричито искључен из покрића. Код осигурања „сви ризици“, било индустрије, било цивила, нема сврхе разматрати питање које ствари или имовина треба да буду искључени из покрића.

Код пожарних полиса „сви ризици“ неопходно је, ради извесности обима покрића, сачинити листу типова имовине која је искључена из покрића. Из осигуравајуће полисе пожарног покрића „сви ризици“ искључени су следећи облици имовине:

- имовина која се не налази на осигураном месту, односно у осигураном објекту,

- творница или погон; 
- животиње и усеви;

- сва возила, укључујући и она која су регистрована за саобраћај на јавним путевима;

- објекти и остала имовина у изградњи, производњи, преради, монтажи, или демонтажи;

- имовина ускладиштена на отвореном, или која захтева посебан начин складиштења попут хладњача, имовина испод земље или под водом;

- земљиште, вода, ваздух;

- ванкопнене инсталације;

- драгоцености, новац, чекови, поштански чекови, злато, сребро, деонице и друге хартије од вредности;

- наменски објекти - шатори, путеви, пруге, тунели, мостови, канали, молови, писте, извори, цевоводи;

- нуклеарна постројења.

Уговарач осигурања има право да прошири покриће брисањем искључене имовине са листе искључења плаћањем одговарајуће премије. Искључења зависе од врсте имовине која се осигурава, али се као типична наводе штете настале због својстава осигуравајућих ствари, скривене мане, замора материјала, корозије, трулежи, испаривања, загађења итд.

Осигуравач, по правилу, дефинише извесна стандардна искључења у условима пожарног осигурања „сви ризици“, посебно за индустрију и посебно за цивил, да се уговарач осигурања не би оптерећивао скупом ценом осигурања имовине коју ионако нема, или је она осигурана на неки други начин.

\section{3. Недостаци пожарног осигурања на бази „сви ризици}

Ради лакшег разумевања појма „сви ризици“ неопходно је позабавити се и са њиховим недостацима. Они су далеко истраженији на светском тржишту, где се овај вид покрића много више примењује него у Србији. По својој природи ова покрића су ризичнија од покрића по осталим условима имовинских осигурања. Дакле, приликом дефинисања, услови се морају пажљиво саставити и уравнотежити због специфичних мана које се огледају у опасности по осигуравача од грешке, промене ризика и ризика нестручног рада осигуравача.

У циљу побољшања услова осигурања по начелу „сви ризици“ сваки покушај мора да се креће у границама начела осигурљивости [3]. Имајући ово у виду, услови осигурања треба да испуњавају следећа два услова:

- отвореност -која подразумева постојање јавности о томе шта осигуравач, закључењем полисе „сви ризици“, преузима као своју обавезу, где осигуравач нема обавезу према осигуранику и

-могућност одређивања адекватне ризико-премије.

Покриће опасности по полиси „сви ризици“ мора да има таква својства која омогућују правичну накнаду након разорних штетних догађаја. Оно мора да задовољи стварне потребе осигураника, пошто покриће учесталих и ситних ризика и штета једноставно није исплативо осигуранику.

Грешке обично настају када није могуће утврдити, односно описати развој и тренутно стање портфеља са довољном прецизношћу. Грешке настају услед непотпуних, нетачних, или нетачно интерпретираних статистичких података. Осигурање по начелу „свих ризика“ је осетљивије од покрића по начелу „именованих ризика“, јер је често много теже извршити категоризацију свих покривених штета, па зато може бити врло тешко утврдити разлоге који су довели до колебања у кретању штета.

Поред опасности од грешке, могућност промене ризика је такође битна за осигуравача. За разлику од опасности од грешке, могућност промене ризика тиче се будућег развоја догађаја и околности у вези са ризиком. Ради се о могућности да стварни меродаван технички резултат знатно одступа од очекиваних пројекција, због нпр., непредвиђених техничких, друштвених, политичких и законских промена. Посебно је у осигурањима од ризика изливања воде, тј. поплава, уочен тренд опремања кућа са вредним и луксузним стварима, што доводи до све већих одштетних захтева.

Поред опасности од настанка грешке, приликом утврђивања акумулације обавеза или погрешног одређивања премије, проблем спровођења осигурања по начелу „свих ризика“ повезан је са иритантним извором опасности као што је пословни ризик. У осигурању индустрије, често су карактеристичне полисе чији се посебни услови и високе своте осигурања тј. лимити, дефинишу мешавином стандардних и посебних клаузула. Грешке у састављању оваквих полиса су честе, па када се деси осигурани случај, то за последицу често има непријатне разговоре и спор који се, по правилу, окончава пресудом на штету осигуравача.

\section{3. ТРЖИШНИ ПОКАЗАТЕЉИ ОСИГУРАњА ОД ПОЖАРА У СРБИЈИ 2013-2017.}

У овом делу рада биће истражено неколико показатеља из којих ће се моћи извести закључци о стању на тржишту пожарног осигурања у Србији током последњих пет година. У питању су званични подаци Народне банке Србије о премији и штетама у осигурању имовине од пожара и других опасности.

Табела 1. Премија осигурања имовине од пожара $u$ других опасности, 2013-2017. година [4]

\begin{tabular}{|l|c|c|c|c|c|}
\hline & 2013. & 2014. & 2015. & 2016. & 2017. \\
\hline $\begin{array}{l}\text { Број } \\
\text { осктурања }\end{array}$ & 149.657 & 146.592 & 158.527 & 169.650 & 170.570 \\
\hline $\begin{array}{l}\text { Премнја } \\
\text { осктурања } \\
\text { (мит. днн.) }\end{array}$ & 4.350 & 4.360 & 5.071 & 5.012 & 5.411 \\
\hline $\begin{array}{l}\text { Техничка } \\
\text { премнја } \\
\text { (мит. днн.) }\end{array}$ & 2.964 & 2.969 & 3.472 & 3.432 & 3.706 \\
\hline
\end{tabular}


Током посматраних пет година у нашој земљи се запажају повољна кретања на тржишту пожарног осигурања (Табела 1). Готово непрекидно се повећава број издатих полиса. Године 2017. било их је око 21.000 више него у 2013. С тим у складу расте и укупна премија ове врсте осигурања. У анализираном раздобљу нарасла је готово за једну четвртину. Техничка премија служи за измирење обавеза према осигураницима по основу уговора о осигурању, као што је истакнуто у једном од претходних делова овог рада. Њено кретање током раздобља 2013-2017. је у складу с кретањем укупне премије осигурања, што је логичан и очекивани налаз.

Табела 2. Штете у осигурану имовине од пожара $u$ других опасности, 2013-2017. година [4]

\begin{tabular}{|l|c|c|c|c|c|}
\hline & 2013. & 2014 & 2015. & 2016. & 2017. \\
\hline $\begin{array}{l}\text { Број пркјављенкх } \\
\text { штета }\end{array}$ & 8.048 & 13.102 & 8.450 & 10.531 & 11.581 \\
\hline $\begin{array}{l}\text { Број обрачунатих } \\
\text { штета }\end{array}$ & 6.306 & 9.054 & 6.617 & 8.246 & 8.829 \\
\hline $\begin{array}{l}\text { Износ } \\
\text { обрачунатих } \\
\text { штета (мит. дин.) }\end{array}$ & 1.727 & 2.410 & 4.225 & 1.428 & 1.541 \\
\hline
\end{tabular}

Као што је познато, штете у осигурању настају као последица остварења ризика који су будући, независни и случајни догађаји. Због тог разлога број пријављених штета у осигурању од пожара у Србији нема неку правилност у кретању по анализираним годинама (Табела 2). Број обрачунатих штета непосредно је повезан са пријављеним штетама, тако да је у годинама када је пријављено највише штета $(2014,2017)$ било највише и обрачунатих штета. Новчани износ обрачунатих штета био је убедљиво највиши 2015. године. Тада је било мање штета од пожара, али су њихове последице очигледно биле најозбиљније.

\section{4. ЗАКЉУЧАК}

У свету, па и у Србији, дугогодишњи, па и вековни приступ осигурању од пожара, темељио се на начелу именованих, тј. тачно побројаних опасности. Савремени захтеви привреде и становништва, допринели су да се најпре уведе, а потом и значајно развије начело „сви ризици”, које пружа широко осигуравајуће покриће.
У овом раду је обављено и посебно истраживање које је обухватило кретање премије осигурања и штета у нашој земљи током временског раздобља 2013-2017. Основни налаз је био да се премија штета пожарног осигурања у земљи готово по правилу увећава из године у годину. Кретање штета зависи од остварења ризика на шта осигуравајућа друштва готово да не могу утицати.

Као сводни закључак из овог рада може се навести да што се брже буде развијало тржиште осигурања у Србији, то ће наше осигурање од пожара бити сличније савременом пожарном осигурању у свету. Такође, све већом применом заштите од пожара више he се примењивати и осигурање од пожара као нужна мера у целовитом програму управљања ризицима.

\section{5. ЛИТЕРАТУРА}

[1] Н. Жарковић, „Осигурање“, Висока школа струковних студија за економију и управу, Београд, 2013, стр. 125.

[2] Feuerversicherung im Wandel der Zeit, Swiss Re, Zurich, 1986, стр. 40.

[3] Б. Берлинер, Limits of insurability of risks, Engelwoo Cliffs, Prentice-Hall, 1982, стр. 43.

[4] Народна банка Србије, www.nbs.rs. (приступљено у септембру 2018.)

\section{Кратка биографија:}

Бранислав Трифуновић рођен је у Бачкој Паланци 1969. год. Мастер рад на Факултету техничких наука из области Инжењерског менаџмента - Управљање ризицима и менаџмент осигурања одбранио је 2018. год. 